\title{
Mechanical Properties of Green Wood and Their Relevance for Tree Risk Assessment
}

\author{
Hanns Christof Spatz and Jochen Pfisterer
}

\begin{abstract}
In a biological context, the mechanical properties as elasticity and strength of green wood, particularly as measured in the axial direction, influence the stability of trees against static loads (e.g., snow, ice, rain) and dynamic loads (i.e., wind). Extensive collections of data on mechanical properties are listed in three different catalogs edited in Canada, Great Britain, and the United States. A statistical analysis shows that the density of the wood is a major predictor for the mechanical properties as measured in axial direction. In this respect, conifers from temperate zones and deciduous trees both from temperate and tropical zones do not differ significantly from each other. A common, nearly linear relation between the modulus of elasticity and the density at $50 \%$ moisture content is found. Relationships between strengths in bending, compression, and shear and green wood density have ordinary least squares scaling exponents around 1.2, but can almost equally well be approximated by linear functions of wood density. Therefore, if the density of stem wood of a given tree is known from direct measurement and differs from the tabulated value, the values tabulated for mechanical properties can be corrected for by a simple rule of proportion.

Pulling tests as tools for tree control are discussed with emphasis on how the method is based on the knowledge of the mechanical properties of green wood, and how wood density is measured. Key Words. Conifers; Deciduous trees; Elasticity; Green wood; Pulling Tests; Strength; Wood density.
\end{abstract}

For many centuries dried wood has been used for construction and engineering purposes. For this, mechanical properties had to be known, particularly the elasticity and strength in the axial direction of the wood used. Knowledge of many quite different mechanical properties of wood, like the speed of sound, the sound radiation coefficient, and the loss coefficient, was required for making good musical instruments (Wegst 2006). In contrast, less is known about the mechanical properties of green wood. Summarizing reliable data from the work in different laboratories over a period of up to 50 years, catalogs of mechanical properties of green wood from more than 300 species have been prepared by Jessome (1977, 55 species), Lavers (1983, 161 species), and in the USDA Wood Handbook (Kretschmann 2010, 195 species). Entries in the tables are the density of green wood and key mechanical properties, like the modulus of elasticity and the strength in bending, compression, and shear, mostly but not exclusively, in the axial direction.

A first statistical analysis of the data from the Lavers catalog revealed that wood density appears as a primary determinant of mechanical properties of green wood. Both elasticity and strength-important for assessing tree stability-scale with exponents near or slightly higher than 1.0 (proportionality) with density (Niklas and Spatz 2010). This was affirmed by Pfisterer and Spatz (2012) who extended the analysis of the data for deciduous trees from the three catalogs. Included in the same paper is a critical review of the widely used "Stuttgart table of wood strength" for interpreting pulling test (Wessolly and Erb 1998; Brudi and van Wassenaer 2001), where the dependency from wood density is not apparent. In this communication the previous analyses were extended by including the data for conifers in the statistical analysis of the entries from the three most important catalogs (Jessome 1977; Lavers 1983; Kretschmann 2010). This way, the mechanical properties for conifers from temperate zones and for deciduous trees from both temperate and tropical zones can be directly compared. A comparison between the three catalogs is also presented, showing that the catalogs mutually support each other. As a result of the statistical analysis, the authors present simple equations, which relate the mechanical properties of green wood, as measured in axial direction, to reference values of its density. The relations between the maximal bending strength, the yield strength, and the maximal compression strength, are also given.

For a diagnosis of living trees, suspected of being unstable, pulling tests can be executed (Milne 1991; Wessolly und Erb 1998; Bruechert et al. 2000; Brudi and Van Wassenaer 2001; Peltola 2006). The following details how mechanical properties, like the modulus of elasticity and the strength properties, enter into the calculations of tree stability and why a reliable source of data on the mechanical properties is essential for the interpretation of the data of such tests. Special attention is also paid to the problem of estimating wind forces acting on trees.

One of the goals of this communication is to extract and summarize some of the information hidden in the comprehensive tables presented by Jessome (1977), Lavers (1983), and Kretschmann (2010). Another is to draw attention to the wealth of information in these catalogs and to encourage arborists to use these well-documented and reliable data, in particular those from the easily accessible USDA Wood Handbook, in tree risk assessment. 


\section{METHODS}

\section{Data Base}

The data analyzed for this communication are taken from the catalogs of Jessome (1977), Lavers (1983), and Kretschmann (2010). With one exception, all entries were included where the mechanical properties of green wood were listed. The exception was the entry for Mgongo in the Lavers catalog, where the species was not clearly identifiable. The analysis represents 306 different species and subspecies. Some species/ subspecies were listed in two or even all three catalogs; however, they were treated separately in this analysis. This led to a total of 393 entries for species and subspecies, and in some cases for the same species/subspecies from different regions.

\section{Definitions}

In the Jessome catalog (1977) and the USDA Wood Handbook (Kretschmann 2010) the density of wood is given as "weight when oven dry over volume when green." This is a workable but somewhat unrealistic definition. However, Lavers (1983), who showed that the mechanical properties of wood change little above a moisture content of $50 \%$, gives the density of green wood at 50\% moisture content (which does not imply that all measurements were conducted at this moisture content). Adopting Lavers' definition, the entries in the other two catalogs were multiplied by a factor of 1.5 to obtain realistic reference values.

Two definitions of strength are used in the literature, either the maximum in the stress-strain relation for a given material or the stress at the deviation from linearity (yield stress) in the stressstrain relation. Reported here are data for the maximal stress in bending, compression, and shear. The relation between maximum stress and yield stress in bending will be discussed later.

\section{Statistics}

Three different protocols were applied: (1) a linear ordinary least squares (OLS) regression including the origin $(y=a \cdot x)$, (2) a linear OLS regression not including the origin $(\mathrm{y}=\mathrm{b} \cdot \mathrm{x}+\mathrm{c})$, and (3) an OLS fit with a power function $\left(y=\beta \cdot x^{\alpha}\right)$. In order to establish a functional relationship reduced mayor axes (RMA) regression is appropriate (Niklas and Spatz 2012a). For this the scaling exponent $\alpha R M A$ was calculated using the formula $\alpha R M A=\alpha O L S / R$, where $R$ is the correlation coefficient (see Niklas and Spatz 2012 b, section 10.4 , and the literature cited there for a more detailed discussion of the differences and merits of RMA versus OLS analyses).

\section{RESULTS}

The modulus of elasticity (MOE) of green wood from conifers and deciduous trees is plotted against the density in Figure 1. Irrespective of whether the samples tested originate from conifers or deciduous trees, or whether from trees grown in tropical zones or temperate regions, the data can be represented by a common trend line.
The correlations between MOE and density are given in the Appendix. Clearly, density is a reasonable predictor, although deviations from the common trend line exist. As pointed out by Lavers (1983), these reflect differences between individual trees even within the same stand, soil conditions, and climatic differences. For large sample sizes, the differences may average out to a certain degree; however, particularly for tropical trees, the sample sizes were often limited.

A similar correlation between mechanical properties and density is seen in Figure 2, Figure 3, and Figure 4. Again the data can be represented by common trend-lines, although the compression strength of deciduous trees from temperate zones seems to be somewhat lower than for those from tropical zones. In bending strength, compression strength and shear strength the deviations from the trend-lines are smaller than in case of the modulus of elasticity (Figure1).

A detailed statistical analysis is presented in the Appendix. The formula used in Protocol 1 predicts a simple proportionality (e.g., linear relation) between mechanical property and density of green wood. From a physics perspective, this is more reasonable than the formula used in Protocol 2, which allows for a finite intercept c, since at density zero the modulus of elasticity and the strengths should also diminish. It should be noted that the coefficient of determination $R^{2}$ is not very different for the two protocols. The authors have therefore not listed the results obtained using Protocol 2 in the Appendix. Appling Protocol 3 , which serves primarily as a test for linearity, leads to a relation between the modulus of elasticity and green wood density with a weighted average of the scaling exponent of $\alpha O L S$ of 0.98 . The relations between strength properties and green wood density are characterized by a weighted average of the scaling exponent of $\alpha O L S$ of 1.11 , both weighted by the coefficient of determination $R^{2}$ (Appendix).

Quite good agreement between the data from the three cata$\log$ is found, especially if the results of the statistical analysis according to Protocol 1 are compared (Appendix). This supports the notion that the three catalogs mutually support each other.

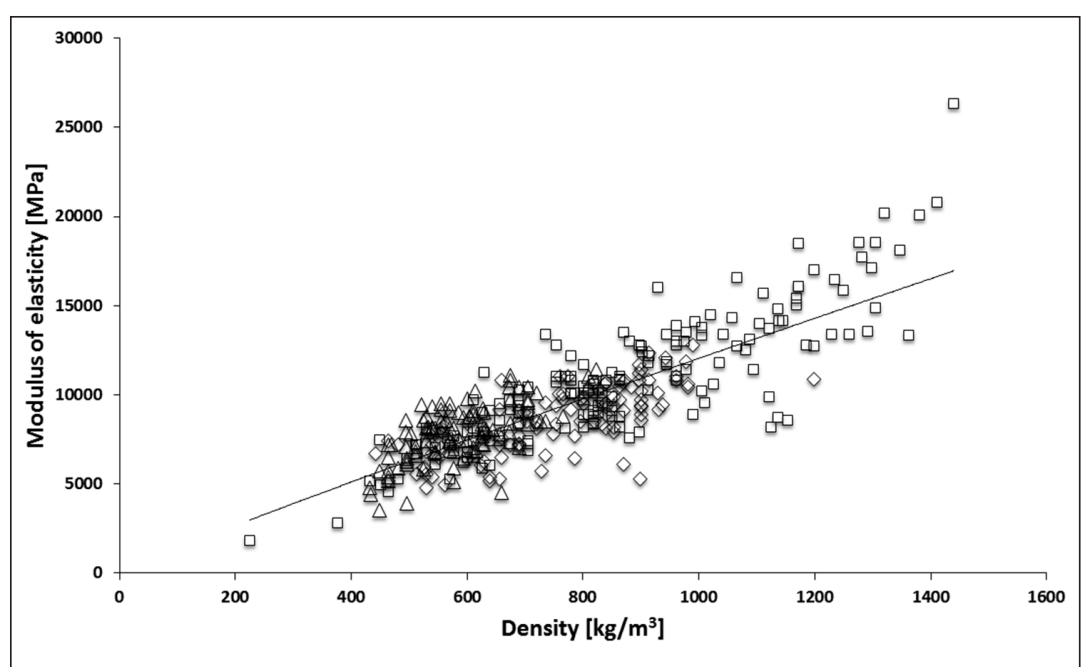

Figure 1. The modulus of elasticity as function of green wood density for conifers from temperate zones (triangles), and deciduous trees from temperate zones (diamonds) and tropical zones (squares). The trend-line drawn is an OLS fit to a power function $\left(y=18.6 \cdot x^{0.94}\right)$. 
Averaged over all trees, the allometric relation between the modulus of elasticity and green wood density has a scaling exponent $\alpha O L S$ of 0.94 . The allometric relations between strength properties and green wood density are characterized by an averaged scaling exponent $\alpha O L S$ of 1.22 (Appendix). The difference from the weighted averages results from the fact that the range of densities of tropical trees is much larger than that of trees from temperate zones, such that the mechanical properties of tropical trees dominate the overall statistics. The biological significance of scaling exponents slightly higher than 1.0 (i.e., linear relation) has been discussed by Niklas and Spatz (2010).

The Appendix also shows the relation between the modulus of elasticity and strength. The scaling exponent $\alpha O L S$ are
1.02 and 1.08 with coefficients of determination of 0.72 for bending strength and 0.69 for compression strength. For shear strength $\alpha O L S=0.79$, but with a coefficient of determination of only 0.47 . It should be noted that all relations shown in the Appendix are representative only for healthy green wood.

\section{DISCUSSION}

The major result of the analysis is that conifers from temperate zones and deciduous trees from both temperate and tropical zones do not differ significantly with respect to the dependence of key mechanical properties of green wood on its density.

The data shown (Figure 1; Figure 2; Figure 3; Figure 4) are averages over several determinations of wood properties from the different species. Lavers (1983) gives the standard deviations, typically $8 \%$ for densities, $16 \%$ for moduli of elasticity, and $15 \%$ for strengths in bending, compression, and shear, where the largest variations are found between trees. Both the density and the mechanical properties of green wood depend on several variables, like the size of its annual rings depending of a year's climate (e.g., summer rainfall, temperature during the growing season, irradiation, fertilizing). Radial variations of the density within the stem have been attributed to changes of the environmental conditions during growth (Woodcock and Shier 2002). Variations also depend on a stem's reaction to mechanical influences, like slanting or partial decay, resulting in the production of adequate reaction wood. The individual tree may therefore differ substantially in its mechanical properties from the population average (Mamdy et al. 1999; Chave et al. 2006).

Wood is an anisotropic material. The most important mechanical properties for the stability of a tree are those in the axial direction. Unfortunately, the strengths cannot be measured directly on a living tree, at least not without major injuries. However, from a practical point of view, the most important implication of the analysis is that it is adequate to measure the density of the wood of a given tree, from which the mechanical properties can be inferred with better approximations, than referring to averaged values for each of the species.

Measurements of the density can be done at low cost by using an increment borer and analyzing the core sample directly (Chave et al. 2006). In trees that are infected with fungi or otherwise pre-damaged, the additional injuries inflicted by this method may be acceptable. A less injurious method is the use of an electronically regulated device recording drilling resistance (Rinn et al. 1996). The resistance recorded is highly correlated with the density of healthy wood. However, it has been mentioned that the moisture content of the wood influences the drilling resistance (Eckstein and $\mathrm{Sa}$ ß 1994). A publication of tangible data would be a desideratum to relate such measurements to standard conditions. It should be noted, that it requires considerable expertise of where to probe and how to interpret the resistance profiles to use the resistance drill as a diagnostic tool.
Figure 3. The maximal compression strength as function of green wood density for conifers from temperate zones (triangles), and deciduous trees from temperate zones (diamonds) and from tropical zones (squares). The trend-line drawn is an OLS fit to a power function $\left(y=0.0061 \cdot x^{1.27}\right)$. 


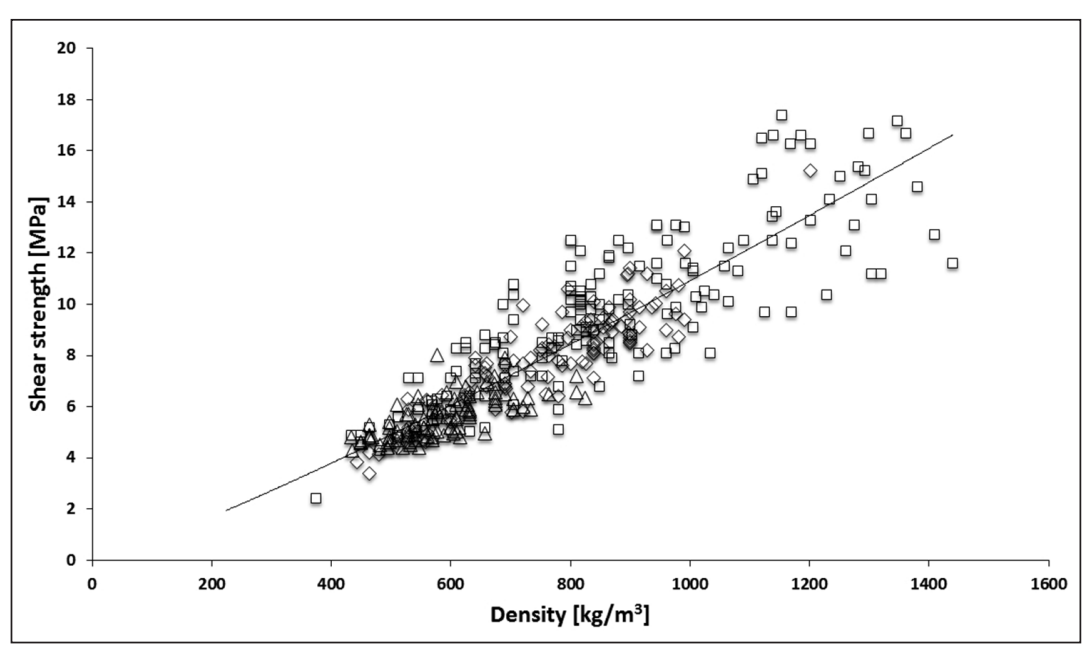

Figure 4. The maximal shear strength as function of green wood density for conifers from temperate zones (triangles), deciduous trees from temperate zones (diamonds) and from tropical zones (squares). The trend-line drawn is an OLS fit to a power function $\left(y=0.0038 \cdot x^{1.15}\right)$.

Another diagnostic tool for tree risk assessment is the pulling test (Milne 1991; Wessolly und Erb 1998; Bruechert et al. 2000; Brudi and Wassenaer 2001; Peltola 2006), which provides a measure of the force necessary to slightly tilt and bend a tree. An inclinometer attached to the base of the trunk reads the degree to which the tree is tilted. The degree of bending is measured with strain gauges attached at various heights of the trunk to measure the strain in the stem just below the bark. Knowing the strain $\varepsilon$ and the outer radius $r$, excluding the bark, the change of curvature of the trunk at the particular height, where the strain gauge is attached, can be calculated. The basic equation for the mechanics of the bending process is given by:

$$
M=E I \frac{\varepsilon}{r}
$$

where $M$ is the bending moment applied (force times lever arm), $E$ is the modulus of elasticity, and $I$ is the second moment of area (Gordon 1976; Niklas and Spatz 2012b). The second moment of area is different for a cross section with a hollow, than for a cross section with solid wood. Taking a value of $E$ from a reliable table, an effective second moment of area $I_{\text {eff }}$ can be computed. If this is compared to the second moment of area for a solid cross section with homogenous material, then a rough indication for the distribution of healthy wood in the cross section can be obtained.

One of the uncertainties in this interpretation may be a distinct difference between tabulated values and the density measured in the tree to be assessed. Since a nearly linear relation exists between MOE and density (Figure 1), a more realistic value for MOE can be obtained by a proportional correction for the density difference:

$$
M O E=M O E_{\text {tabulated }} \frac{\text { density }_{\text {measured }}}{\text { density }}
$$

Another difficulty lies in the accuracy of the determination of the second moment of area according to Equation 1. As mentioned before, the values for the moduli of elasticity have a standard deviation of around $16 \%$. According to the law of error propagation, this reduces to $14 \%$ if the density is known, an error margin, which is still too large to use in this procedure for more than an indication of the degree of hollowness. The evaluation of the degree of hollowness in a tree from pulling tests alone is even more complicated for so-called hazard trees (Mattheck and Breloer 1994) with small $t / r$ ratios, where $t$ is the width of the remaining healthy wood and $r$ is the outer radius. If ovalization of the cross section under bending loads is taken into account, it could be shown that the second moment of area $I_{\text {eff }}$ is considerably smaller than calculated conventionally for an un-deformed cross section (Spatz and Niklas 2013).

Therefore, the diagnosis should follow a different route. Equation 1 can be written in a different form as the following:

$$
\text { [3] } \quad M=\frac{I_{e f f}}{r} \sigma
$$

where $\sigma$ is the stress in the periphery of the stem. It is particularly useful as

[4] $\quad M_{\text {crit }}=\frac{I_{\text {eff }}}{r} \sigma_{\text {crit }}$

where $r$ is the outer radius, excluding the bark, and $\sigma_{c r i t}$ is the maximal bending strength (Figure 2). $M_{c r i t}$ is the bending moment at which failure is expected to occur (Spatz and Brüchert 2000). Realistic estimates for $I_{\text {eff }}$, as can be calculated from sound tomography profiles (Gilbert and Smiley 2004), and $\sigma_{c r i t}$ are found in the Jessome, Lavers, and USDA Wood Handbook tables. Thus, within error limits also given in the tables, the bending moment critical for failure to occur in the trunk of a given tree can be determined according to Equation 4.

Usually, in the interpretation of a pulling test, the critical stress is taken as the stress at the yield point in a stress-strain curve. Therefore, a short excursion into fracture mechanics seems useful to point to the relations between different strength properties.

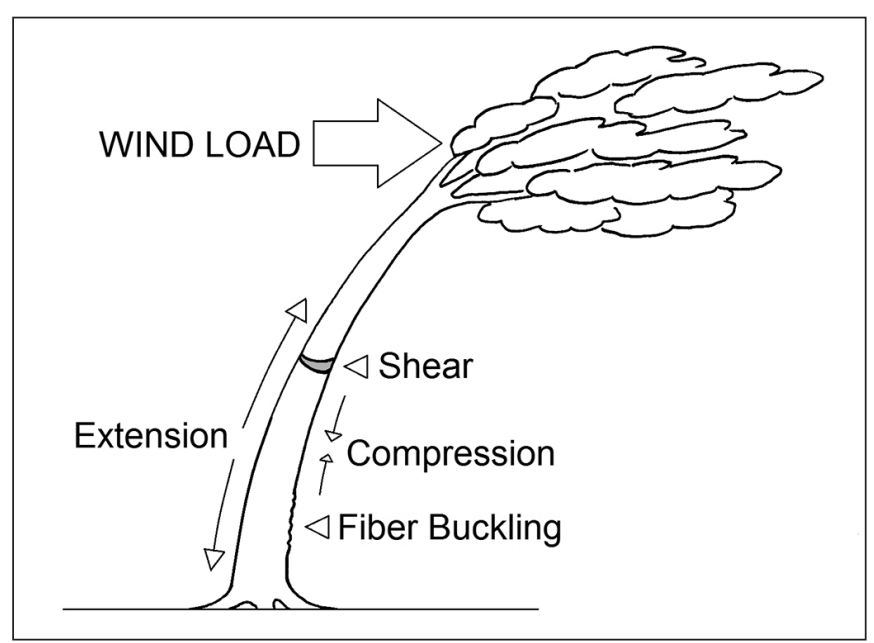

Figure 5. Schematic drawing representing strains in a tree bent under wind loads. Bending, and even more so shear strains, are greatly exaggerated. An arrow points to fiber buckling on the compression side. 
When bending extends beyond the linear range of elastic behavior (i.e., beyond the yield point), plant materials will usually undergo plastic deformations. In green wood it is easy to observe that this deformation is accompanied by buckling of fibers on the compression side (Figure 5). Compression failure by fiber buckling can therefore be identified as the primary failure event (Spatz and Niklas 2013). Although correlations are not necessarily causalities, this notion is supported by a close correlation and a ratio near 1:1 between compression strength and yield strength in bending apparent in the data from the Jessome catalog (see Appendix). This and other relations between strength properties as listed can be summarized:

Maximal compression stress $\approx$ yield stress $\approx 1 / 2$ maximal bending stress.

This critical bending moment calculated on the basis of Equation 4 is compared to the bending moment imposed on the tree at maximal wind loads expected at the particular site and under the particular environmental conditions (Gardiner 1995; Wood 1995; Peltola2006). Not taking into account the actual wind profile (Spatz and Bruechert 2000), the lever arm is taken as the height of the midpoint of the crown. For steady wind the drag force is calculated as:

$$
F_{\text {Drag }}=0.5 \rho A U^{2} C_{D}
$$

where $\rho$ is the density of air, $A$ is the "sailing area" (i.e., the projection of the crown facing the wind), $U$ is the wind velocity at the height of the midpoint of the crown, and $C_{D}$ is the drag coefficient. The practical problem to determining the drag coefficient of a tree is formidable (Vogel 1994). For low wind speeds, the drag coefficient is approximately 0.5 for a fully leaved tree (Mayhead 1973). At high wind speeds, the branches bend to the leeward side to an extent depending on their flexibility. This "streamlining" reduces the sailing area as well as the drag coefficient substantially (Mayhead 1973; Rudnicki et al. 2004; Telewski 2012). This is why for any estimate of the actual wind load on a tree arborists need to know the mechanical properties of the tree investigated.

Under natural conditions, the situation is considerably more complex because real winds are gusty winds and trees react to wind as dynamic structures (James 2003; Spatz et al. 2007; Rodriguez et al. 2008; Sellier et al. 2008) in such a way that flexible branches do not move in line and in phase with the trunk, but rather somewhat independently. In well branched trees this leads to a considerable damping of potentially dangerous oscillations: mechanical energy is distributed quite effectively within the tree and is not so much focused on the trunk and the roots. The energy is also dissipated more effectively in a tree crown with flexible branches than in a tree with stiff branches (Spatz et al. 2007). At the present time, this phenomenon, known as structural damping (Niklas 1992), was described quantitatively only for model trees (Rodriguez et al. 2008). Thus, it is not clear which correction factors for the critical bending moment should be used in Equation 5 to account for the gustiness of wind and the special architecture of the tree crown.

It should be noted that these considerations do not invalidate pulling tests, they just point to the limitations in their expressiveness. Due to the number of approximations necessary, it seems advisable to allow for safety margins of the order of a factor of two in their interpretation. The diagnosis, and even more so the prognosis for a living organism cannot yield certainties, but rather probabilities of failure within the limitation of the methods and the accuracy of the data base.

\section{LITERATURE CITED}

Bruechert, F., G. Becker, and T. Speck. 2000. The mechanics of Norway Spruce [Picea abies (L.) Karst]: The mechanical properties of standing trees from different thinning regimes. Forest Ecology and Management 135:45-62.

Brudi, E., and P. van Wassenaer. 2001. Trees and Statics: Non Destructive Failure Analysis. In: E. Thomas Smiley and K. Coder (Eds.). 2001. Tree Structure and Mechanics Conference Proceedings: How Trees Stand Up and Fall Down. Savannah, Georgia, U.S. pp. 53-69. <www2. tree-consult.org/images/pdf/eng/brudi_trees_and_statics.pdf>

Chave, J., H.C. Muller-Landau, T.R. Baker, T.A. Easdale, H. ter Steege, and C.O. Webb. 2006. Regional and phylogenetic variation of wood density across 2456 neotropical tree species. Ecological Applications 16:2356-2367.

Eckstein, D., and U. Saß. 1994. Bohrwiderstandsmessungen an Laubbäumen und ihre holzanatomische Interpretation. Holz als Roh- und Werkstoff 52:279-286.

Gardiner, B.A. 1995. The interactions of wind and tree movement in forest canopies. pp. 41-59. In: M.P. Coutts and J. Grace (Eds.). Wind and Trees. Cambridge University Press, Cambridge.

Gilbert, E.A., and E.T. Smiley. 2004. Picus sonic tomography for the quantification of decay in white oak (Quercus alba) and hickory (Carya spp.). Journal of Arboriculture 30:277-281.

Gordon, J.E. 1976. The new science of strong materials or why you don't fall through the floor. 2nd edition. Penguin books, London, UK.

James, K. 2003. Dynamic loading of trees. Journal of Arboriculture 29:165-171.

Jessome, A.P. 1977. Strength and related properties of woods grown in Canada. Eastern Forest Products Laboratory, Ottawa, Ontario. Forestry Technical Report 21, Ottawa.

Kretschmann, D.E. 2010. Mechanical properties of wood. In: Wood Handbook. Wood as an engineering material. Forest Products Laboratories, technical report, USDA, Madison, Wisconsin, U.S. 5:1-44.

Lavers, G.M. 1983. The strength properties of timber. 3rd, revised ed. London (Department Environment. Build. Res. Establishment). 60 p.

Mamdy C., P. Rozenberg, A. Franc, J. Launay, N. Scherman, and J.C. Bastien. 1999. Genetic control of stiffness of standing Douglas fir; from the standing stem to the standardized wood sample, relationships between modulus of elasticity and wood density parameters. Part I. Annals of Forest Science 56:133-143.

Mattheck, C., and H. Breloer. 1994. The body language of trees, a handbook for failure analysis. London, England: Her Majesty's Stationary Office.

Mayhead, G.J. 1973. Sway periods of forest trees. Scott. For. 27:19-23.

Milne, R. 1991. Dynamics of swaying of Picea sitchensis. Tree Physiol. 9:383-399.

Niklas, K. 1992. Plant Biomechanics. Univ. Chicago Press, Chicago, Illinois, U.S.

Niklas, K., and H.-Ch. Spatz. 2010. Worldwide correlation of mechanical properties and green wood density. American Journal of Botany 97:1587-1594.

Niklas, K., and H.-Ch. Spatz. 2012a. Mechanical properties of wood disproportionally increase with increasing density. American Journal Botany 99:169-170.

Niklas, K., and H.-Ch. Spatz. 2012b. Plant Physics. Univ. Chicago Press, Chicago, Illinois, U.S.

Peltola, H.M. 2006. Mechanical stability of trees under static loads. American Journal of Botany 93:1501-1511. 
Pfisterer, J., and H.-Ch. Spatz. 2012. Ein Katalog der Steifigkeit und Festigkeit für Holz von Laubbäumen: Beziehungen zwischen mechanischen Eigenschaften frischer Hölzer aus verschiedenen Klimazonen und deren Dichte. AFZ DerWald 8:41-45.

Rinn, F., F.H. Schweingruber, and E. Schär. 1996. Resistograph and $\mathrm{X}$-ray density charts of wood. Comparative evaluation of drill resistance profiles and X-ray density charts of different wood species. Holzforschung 50:303-311.

Rodriguez, M., E. De Langre, and B. Moulia. 2008. A scaling law for the effects of architecture and allometry on tree vibration modes suggests a biological tuning to modal compartmentalization. American Journal of Botany 95:1523-1537.

Rudnicki, M., S.J. Mitchell, and M.D. Novak. 2004. Wind tunnel measurements of crown streamlining and drag relationships for three conifer species. Canadian Journal of Forest Research 34:666-676.

Sellier, D., Y. Brunet, and T. Fourcaud. 2008. A numerical model of tree aerodynamic responses to a turbulent airflow. Forestry 81:279-297.

Spatz, H.-Ch., and F. Brüchert. 2000. Basic biomechanics of selfsupporting plants: Wind loads and gravitational loads on a Norway spruce tree. Forest Ecology Management 135:33-44.

Spatz, H.-Ch., F. Brüchert, and J. Pfisterer. 2007. Multiple resonance damping or how do trees escape dangerously large oscillations? American Journal of Botany 94:1603-1611.

Spatz, H.-Ch., and K.J. Niklas. 2013. Modes of failure in tubular plant organs. American Journal of Botany 100:332-336.

Telewski, F.W. 2012. Is windswept tree growth negative thigmotropism? Plant Science 184:20-28.

Vogel, S. 1994. Life in Moving Fluids. 2nd edition, Princeton University Press, Princeton, New Jersey, U.S.

Wegst, U.G.K. 2006. Wood for sound. American Journal of Botany 93:1439-1448.

Wessolly, L., and M. Erb. 1998. Handbuch der Baumstatik. Patzer Verlag, Berlin, Hannover, Germany.

Wood, C.J. 1995. Understanding wind forces on trees, pp. 133-164. In: M.P. Coutts and J. Grace (Eds.). Wind and Trees. Cambridge University Press, Cambridge.

Woodcock, D.W., and A.D. Shier. 2002. Wood specific gravity and its radial variations: The many ways to make a tree. Trees 16:437-443.

\author{
Hanns Christof Spatz (corresponding author) \\ Institute for Biology III \\ University of Freiburg \\ Germany \\ christof.spatz@live.de
}

\author{
Jochen Pfisterer \\ Institute for Biology III \\ University of Freiburg \\ Germany
}

Zusammenfassung. In einem biologischen Zusammenhang beeinflussen die mechanischen Eigenschaften wie Elastizität und Stärke von Grünholz, gemessen in axialer Richtung, die Stabilität von Bäumen gegenüber statischen (z.B. Schnee, Eis, Regen) und dynamischen (z. B. Wind) Lasten. In drei verschiedenen Katalogen aus Kanada, Großbritannien und den Vereinigten Staaten werden umfangreiche Datensammlungen über mechanische Eigenschaften aufgeführt. Eine statistische Analyse zeigt, dass die Dichte von Holz eine wichtige Größe bei der Vorhersage mechanischer Eigenschaften in axialer Richtung gemessen, darstellt. In dieser Würdigung weichen Koniferen aus gemäßigten Zonen und Laubbäume aus gemäßigten und tropischen Zonen nicht weit voneinander ab. Eine gemeinsame, fast lineare Relation zwischen dem Modus der Elastizität und der Dichte bei 50\% Feuchtegehalt wurde dabei gefunden. Beziehungen zwischen Biegestärke, Kompression, Schub und Dichte des Grünholzes haben gewöhnkliche kleinste Fehlerquadrate um 1.2 aber können ebenso gut durch lineare Funktionen der Holzdichte geschätzt werden. Daher können die Tabellen-Werte für mechanische Eigenschaften, wenn die die Dichte des Stammholzes für einen bestimmten Baum bereits durch direkte Messung bestimmt ist und von den Tabellenwerten abweicht, durch einen simplen Vergleich korrigiert werden.

Zugversuche als Methode der Baumkontrolle werden im Hinblick darauf diskutiert, ob die Methode auf der Kenntnis von den mechanischen Eigenschaften von Grünholz basiert, wie Hozdichte gemessen wird und der Dämpffähigkeit von Baumkronen.

Resumen. En un contexto biológico, las propiedades mecánicas como la elasticidad y resistencia de la madera verde, particularmente medida en dirección axial, influye en la estabilidad de los árboles contra cargas estáticas (por ejemplo, nieve, hielo, lluvia) y cargas dinámicas (como el viento). Una extensa colección de datos sobre las propiedades mecánicas se enseña en tres catálogos diferentes editados en Canadá, Gran Bretaña y Estados Unidos. Un análisis estadístico muestra que la densidad de la madera es un factor de predicción importante para las propiedades mecánicas, medidas en dirección axial. En este sentido, las coníferas de las zonas templadas y los árboles de hoja caduca, tanto de las zonas templadas como de las tropicales, no difieren significativamente entre sí. Se encuentra una relación común, casi lineal, entre el módulo de elasticidad y la densidad a 50\% de contenido de humedad. La relación entre las fuerzas de flexión, compresión y cizallamiento con la densidad de la madera verde tiene exponentes mínimos cuadrados alrededor de 1.2, pero casi se pueden igualar por funciones lineales de densidad de la madera. Por lo tanto, si la densidad de la madera del tronco de un árbol dado se conoce a partir de la medición directa y difiere del valor tabulado, los valores tabulados para las propiedades mecánicas pueden ser corregidos por una simple regla de proporción. Se discuten pruebas de tracción como herramientas para el control de árbol con énfasis en la forma en que el método se basa en el conocimiento de las propiedades mecánicas de la madera verde, cómo se mide la densidad de la madera, y la capacidad de amortiguación de la copa de un árbol. 
Appendix.

Statistical analyses of data presented in three catalogs (Jessome 1977; Lavers 1983; Kretschmann 2010). Results from applying two different protocols are given. The scaling exponents for the allometric representation of the data (Protocol 3) are given both for ordinary least squares (OLS) regression and for reduced major axes (RMA) regression.

\begin{tabular}{|c|c|c|c|c|c|c|}
\hline Statistical protocol & $\begin{array}{l}1 \\
y=a \cdot x \\
a\end{array}$ & $\mathrm{R}^{2}$ & $\begin{array}{l}3 \\
y=\beta \bullet x \\
\alpha O L S\end{array}$ & $\mathrm{R}^{2}$ & $\alpha \mathrm{RMA}$ & Source \\
\hline Deciduous trees from temperate zones & & & & & & \\
\hline Modulus of elasticity versus density & $\begin{array}{l}11.2 \\
11.0 \\
11.9\end{array}$ & $\begin{array}{l}0.47 \\
0.68 \\
0.37\end{array}$ & $\begin{array}{l}0.72 \\
1.18 \\
0.67\end{array}$ & $\begin{array}{l}0.54 \\
0.66 \\
0.39\end{array}$ & $\begin{array}{l}0.98 \\
1.45 \\
1.07\end{array}$ & $\begin{array}{l}\text { USDA } \\
\text { Lavers } \\
\text { Jessome }\end{array}$ \\
\hline Bending strength versus density & $\begin{array}{l}0.072 \\
0.078 \\
0.068\end{array}$ & $\begin{array}{l}0.78 \\
0.81 \\
0.77\end{array}$ & $\begin{array}{l}1.15 \\
1.30 \\
1.10\end{array}$ & $\begin{array}{l}0.84 \\
0.85 \\
0.79\end{array}$ & $\begin{array}{l}1.25 \\
1.41 \\
1.24\end{array}$ & $\begin{array}{l}\text { USDA } \\
\text { Lavers } \\
\text { Jessome }\end{array}$ \\
\hline $\begin{array}{l}\text { Compression strength } \\
\text { versus density }\end{array}$ & $\begin{array}{l}0.031 \\
0.034 \\
0.029\end{array}$ & $\begin{array}{l}0.70 \\
0.73 \\
0.68\end{array}$ & $\begin{array}{l}1.10 \\
1.14 \\
1.00\end{array}$ & $\begin{array}{l}0.76 \\
0.73 \\
0.69\end{array}$ & $\begin{array}{l}1.26 \\
1.33 \\
1.20\end{array}$ & $\begin{array}{l}\text { USDA } \\
\text { Lavers } \\
\text { Jessome }\end{array}$ \\
\hline Shear strength versus density & $\begin{array}{l}0.0103 \\
0.0113 \\
0.0102\end{array}$ & $\begin{array}{l}0.80 \\
0.83 \\
0.83\end{array}$ & $\begin{array}{l}1.26 \\
1.29 \\
1.19\end{array}$ & $\begin{array}{l}0.86 \\
0.87 \\
0.87\end{array}$ & $\begin{array}{l}1.36 \\
1.38 \\
1.28\end{array}$ & $\begin{array}{l}\text { USDA } \\
\text { Lavers } \\
\text { Jessome }\end{array}$ \\
\hline $\begin{array}{l}\text { Bending Strength versus } \\
\text { yield strength in bending }\end{array}$ & 2.07 & 0.91 & 1.10 & 0.92 & 1.15 & Jessome \\
\hline $\begin{array}{l}\text { Compression Strength versus } \\
\text { yield strength in bending }\end{array}$ & 0.890 & 0.91 & 1.06 & 0.92 & 1.11 & Jessome \\
\hline Deciduous trees from the tropics & & & & & & \\
\hline Modulus of elasticity versus density & $\begin{array}{l}13.2 \\
12.2\end{array}$ & $\begin{array}{l}0.74 \\
0.71\end{array}$ & $\begin{array}{l}1.08 \\
0.98\end{array}$ & $\begin{array}{l}0.78 \\
0.75\end{array}$ & $\begin{array}{l}1.22 \\
1.13\end{array}$ & $\begin{array}{l}\text { USDA } \\
\text { Lavers }\end{array}$ \\
\hline Bending strength versus density & $\begin{array}{l}0.088 \\
0.093\end{array}$ & $\begin{array}{l}0.79 \\
0.84\end{array}$ & $\begin{array}{l}1.30 \\
1.14\end{array}$ & $\begin{array}{l}0.86 \\
0.85\end{array}$ & $\begin{array}{l}1.40 \\
1.24\end{array}$ & $\begin{array}{l}\text { USDA } \\
\text { Lavers }\end{array}$ \\
\hline Compression strength versus density & $\begin{array}{l}0.044 \\
0.048\end{array}$ & $\begin{array}{l}0.73 \\
0.84\end{array}$ & $\begin{array}{l}1.28 \\
1.21\end{array}$ & $\begin{array}{l}0.81 \\
0.85\end{array}$ & $\begin{array}{l}1.42 \\
1.31\end{array}$ & $\begin{array}{l}\text { USDA } \\
\text { Lavers }\end{array}$ \\
\hline Shear strength versus density & $\begin{array}{l}0.0100 \\
0.0121\end{array}$ & $\begin{array}{l}0.74 \\
0.79\end{array}$ & $\begin{array}{l}1.05 \\
1.11\end{array}$ & $\begin{array}{l}0.81 \\
0.80\end{array}$ & $\begin{array}{l}1.17 \\
1.24\end{array}$ & $\begin{array}{l}\text { USDA } \\
\text { Lavers }\end{array}$ \\
\hline Conifers from temperate zones & & & & & & \\
\hline Modulus of elasticity versus density & $\begin{array}{l}13.4 \\
12.6 \\
14.5\end{array}$ & $\begin{array}{l}0.31 \\
0.49 \\
0.41\end{array}$ & $\begin{array}{l}0.76 \\
1.21 \\
1.03\end{array}$ & $\begin{array}{l}0.33 \\
0.49 \\
0.40\end{array}$ & $\begin{array}{l}1.32 \\
1.73 \\
1.63\end{array}$ & $\begin{array}{l}\text { USDA } \\
\text { Lavers } \\
\text { Jessome }\end{array}$ \\
\hline Bending strength versus density & $\begin{array}{l}0.072 \\
0.076 \\
0.069\end{array}$ & $\begin{array}{l}0.81 \\
0.72 \\
0.76\end{array}$ & $\begin{array}{l}1.02 \\
1.22 \\
1.07\end{array}$ & $\begin{array}{l}0.80 \\
0.76 \\
0.74\end{array}$ & $\begin{array}{l}1.14 \\
1.40 \\
1.24\end{array}$ & $\begin{array}{l}\text { USDA } \\
\text { Lavers } \\
\text { Jessome }\end{array}$ \\
\hline $\begin{array}{l}\text { Compression strength } \\
\text { versus density }\end{array}$ & $\begin{array}{l}0.035 \\
0.036 \\
0.034\end{array}$ & $\begin{array}{l}0.64 \\
0.63 \\
0.68\end{array}$ & $\begin{array}{l}0.94 \\
1.08 \\
1.03\end{array}$ & $\begin{array}{l}0.66 \\
0.63 \\
0.66\end{array}$ & $\begin{array}{l}1.16 \\
1.36 \\
1.27\end{array}$ & $\begin{array}{l}\text { USDA } \\
\text { Lavers } \\
\text { Jessome }\end{array}$ \\
\hline Shear strength versus density & $\begin{array}{l}0.0093 \\
0.0102 \\
0.0088\end{array}$ & $\begin{array}{l}0.52 \\
0.51 \\
0.52\end{array}$ & $\begin{array}{l}0.73 \\
0.93 \\
0.72\end{array}$ & $\begin{array}{l}0.62 \\
0.54 \\
0.62\end{array}$ & $\begin{array}{l}0.92 \\
1.27 \\
0.91\end{array}$ & $\begin{array}{l}\text { USDA } \\
\text { Lavers } \\
\text { Jessome }\end{array}$ \\
\hline
\end{tabular}




\begin{tabular}{|c|c|c|c|c|c|c|}
\hline Statistical protocol & $\begin{array}{l}1 \\
y=a \cdot x \\
a\end{array}$ & $\mathrm{R}^{2}$ & $\begin{array}{l}3 \\
y=\beta \cdot x^{\alpha} \\
\alpha \mathrm{OLS}\end{array}$ & $\mathrm{R}^{2}$ & $\alpha \mathrm{RMA}$ & Source \\
\hline $\begin{array}{l}\text { Bending strength versus yield } \\
\text { strength in bending }\end{array}$ & 1.80 & 0.88 & 0.88 & 0.90 & 0.93 & Jessome \\
\hline $\begin{array}{l}\text { Compression strength versus } \\
\text { yield strength in bending }\end{array}$ & 0.88 & 0.94 & 0.92 & 0.94 & 0.95 & Jessome \\
\hline All Trees & & & & & & \\
\hline Modulus of elasticity versus density & 12.4 & 0.71 & 0.94 & 0.68 & 1.14 & \\
\hline Bending strength versus density & 0.082 & 0.79 & 1.25 & 0.84 & 1.36 & \\
\hline $\begin{array}{l}\text { Compression strength } \\
\text { versus density }\end{array}$ & 0.040 & 0.69 & 1.27 & 0.74 & 1.48 & \\
\hline Shear strength versus density & 0.0108 & 0.78 & 1.15 & 0.81 & 1.28 & \\
\hline $\begin{array}{l}\text { Bending strength versus } \\
\text { modulus of elasticity }\end{array}$ & 0.0066 & 0.75 & 1.02 & 0.72 & 1.20 & \\
\hline $\begin{array}{l}\text { Compression strength versus } \\
\text { modulus of elasticity }\end{array}$ & 0.0032 & 0.70 & 1.08 & 0.69 & 1.30 & \\
\hline $\begin{array}{l}\text { Shear strength versus modulus } \\
\text { of elasticity }\end{array}$ & 0.00084 & 0.43 & 0.79 & 0.47 & 1.15 & \\
\hline
\end{tabular}

